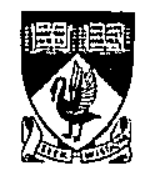

LONGITUDINAL ANALYSIS OF IMMIGRANT OCCUPATIONAL MOBILITY: A TEST OF THE IMMIGRANT ASSIMILATION HYPOTHESIS

by

Barry R. Chiswick

Yew Liang Lee

and

Paul W. Miller

DISCUSSION PAPER 02.08

DEPARTMENT OF ECONOMICS

THE UNIVERSITY OF WESTERN AUSTRALIA

35 STIRLING HIGHWAY

CRAWLEY, WA 6009

AUSTRALIA 
Preliminary

February 2002

Not for citation without permission of an author.

LONGITUDINAL ANALYSIS OF IMMIGRANT OCCUPATIONAL MOBILITY: A TEST OF THE IMMIGRANT ASSIMILATION HYPOTHESIS

by

\author{
Barry R. Chiswick \\ Department of Economics \\ University of Illinois at Chicago \\ Yew Liang Lee \\ Department of Economics \\ University of Western Australia \\ Paul W. Miller* \\ Department of Economics \\ University of Western Australia
}

JEL Codes: J15, J24, J61, J62

* Miller acknowledges financial assistance from the Australian Research Council. 


\title{
LONGITUDINAL ANALYSIS OF IMMIGRANT OCCUPATIONAL MOBILITY: A TEST OF THE IMMIGRANT ASSIMILATION HYPOTHESIS
}

\begin{abstract}
Using an immigrant assimilation framework, this paper develops a model of the occupational mobility of immigrants and tests the hypotheses using data on adult males from the Longitudinal Survey of Immigrants to Australia. The theoretical model generates hypotheses regarding a U-shaped pattern of occupational mobility from the "last job" in the origin, to the "first job" in the destination, to subsequent jobs in the destination, and regarding the depth of the "U." The survey includes data on pre-immigration occupation, the "first" occupation in Australia (at 6 months) and the occupation after about 3.5 years in Australia. The hypotheses are supported by the empirical analysis. (100 words).
\end{abstract}




\section{IMMIGRANT OCCUPATIONAL MOBILITY: A TEST OF THE IMMIGRANT ASSIMILATION HYPOTHESIS}

\section{Introduction}

The labor market adjustment of immigrants has been of intense research interest among economists for the past two decades. Research in this area has been conducted for occupational attainment, earnings and employment/unemployment (for the earliest studies, see Chiswick, 1977, 1978, 1982). This research has been conducted primarily using cross-sectional data from the major immigrant receiving countries: primarily the United States, Canada, Australia, Israel and Germany. It has documented that the labor market attainment of immigrants varies systematically with human capital and demographic variables, and in particular increases with duration of residence in the destination. Yet the effect of duration, or years since migration, on labor market outcomes observed in cross-sectional data may not be an unbiased estimate of the longitudinal effect that individuals experience.' The cross-section may provide biased estimates of the longitudinal effects if there is selectivity in the return migration of immigrants or if there are changes over time in the unmeasured dimensions of the quality of immigrants. In particular, the cross-section provides upward biased estimates if the least successful of immigrants have a greater propensity to remigrate or if more recent immigrant cohorts have lower unmeasured dimensions of ability relevant for the labor market.

The "best" estimates of the longitudinal progress of immigrants would, of course, come from longitudinal data. Yet, longitudinal data on immigrants are quite

\footnotetext{
$\overline{1}$ This point was first made and tested in Chiswick 1980.
} 
scarce. Some studies have used longitudinal data on adult males: (1) occupation in 1965 and 1970 in the U.S. 1970 Census (Chiswick 1977), (2) earnings in the National Longitudinal Survey of Adult Males (Chiswick 1980), (3) earnings from matched samples from the Current Population Survey (Duleep and Regets 1997), and (4) earnings of scientists from National Science Foundation data (Borjas 1989), although the latter suffers from selective movement in and out of scientific occupations. An alternative approach has been to use "synthetic cohorts," that is, following over time samples defined by year of immigration and age (Borjas 1985). The latter approach has inherent problems due to selective emigration, changes in the composition of the samples over time, and the difficulty of disentangling longitudinal changes and period (timing) effects (Chiswick 1986, Duleep and Regets 1996). ${ }^{2}$

The approach taken in this paper is to exploit a true longitudinal survey of immigrants in Australia. This survey provides data on occupational attainment prior to immigration, as well as occupational attainment in three survey waves that span a period of approximately $31 / 2$ years following immigration. Thus, it provides data on occupation prior to and in the early period after immigration.

Section II develops the theory and the testable hypotheses regarding the occupational change of immigrants from the pre-immigration to the post-immigration period. Section III discusses the Longitudinal Survey of Immigrants to Australia, which provides the data for testing the hypotheses. The empirical analysis is presented in Section IV, first as descriptive statistics regarding occupational level and change, and then using multiple regression (econometric) techniques. Due to the categorical nature of the dependent variable, occupational level or change, a socioeconomic status variable for occupation that has been developed for Australia is used in the

2 Other studies of occupational attainment in various countries include: Broom, et al. 1977, Brown, et al. 1980, Featherman, et al. 1975, Leigh 1975, Miller and Volker 1985, Nickell 1982, Schmidt and Strauss 1975. 
econometric analysis. At this stage the analysis is limited to adult (non-aged) males for two reasons. One is that the labor force participation decision would be crucial for an analysis for females and aged males, and to do this would add additional complexity to the analysis. The other is the relatively small size of the sample of females and aged males. This paper closes (Section V) with a section that summarizes the findings and draws out implications.

\section{The Theory of Immigrant Occupational Mobility ${ }^{3}$}

Consider individuals in a country of origin who are contemplating international migration. They analyze the expected increase in their economic wellbeing by considering the present value of expected earnings in the origin and destination, and the costs of migration. The costs include not merely the time and transport costs of the move, but rather the full range of costs associated with leaving an origin and re-establishing oneself in a new location, including acquiring information specific to the destination. In this approach the migrants are not concerned with their occupational labels in the origin and destination, but rather with the real eamings that they can receive.

To the extent that there are differences in real wages across countries, migrants flow from the low-wage origin to the high-wage destination country. Yet "skills" may not be perfectly transferable across countries. These skills are to be defined broadly to include labor market information, destination language proficiency, occupational licenses, certifications or credentials, as well as more narrowly defined task-specific skills. Consider three high-level occupations, economist, medical doctor and lawyer. Country-specific skills for the economist may include language and style of practice.

\footnotetext{
${ }^{3}$ This analysis builds upon the model in Chiswick 1977.
} 
The medical doctor has less transferable skills because, in addition to language and style of practice, medical license requirements prohibit the practice of medicine until after acquiring a license specific to the destination. The skills of lawyers are even less transferable across countries because, in addition to the above, the legal system (as distinct from economic theory and the human body) varies sharply across countries.

The lower the transferability of skills the greater will be the decline in occupational status from the "last" permanent job in the origin to the "first" job in the destination. After migration, however, immigrants make implicit and explicit investments that complement the skills they bring with them to increase the transferability of these skills to the destination.

These investments include learning about the labor market, the language, and the style of practice, as well as acquiring new skills and obtaining whatever licenses, certifications and other credentials that will enhance productivity in the destination labor market (Chiswick and Miller, forthcoming). As a result, occupational status and earnings would increase with duration in the destination. Thus, the refugee lawyer may start out as a restaurant dishwasher, move on to becoming a librarian, translator or para-legal, and then possibly move up to becoming a lawyer.

The decline in occupational status from the last job in the origin to the first job in the destination, followed by the subsequent rise with duration in the destination can be described as a "U-shaped" pattern. The degree of subsequent increase in the destination will be related to the initial decline from the origin to the destination. The steeper the decline, on average, the steeper the subsequent increase.

Immigrants from countries very similar to the destination, for example, an English-speaking Canadian moving to the United States, may experience little or no 
downward mobility on migration and hence will experience little subsequent increase. $^{4}$ When skills are highly transferable the immigrants will have a shallow "U". Immigrants without skills or with only very low levels of skill are not likely to make large investments in skills in the destination. ${ }^{5}$ They will experience little or no decline in occupational status as they have few if any skills, and hence little or no subsequent increase. They, too, will have a shallow " $U$ ".

In the more typical case for economic migrants from a lower income origin to a higher income destination the immigrant has some skills that are not perfectly transferable. As a result, there will be a decline in occupational status from the last job in the origin to the first job in the destination (which may even provide a higher wage than was received in the origin), with a subsequent improvement. Those with the least transferable skills among potential migrants are not likely to become economic migrants. Economists and computer scientists have higher rates of international migration than do physicians, who in turn have higher rates of international migration than do lawyers.

Refugees and tied movers, on the other hand, base their migration decision on a different set of calculations. While incomes in the origin and destination are surely relevant, by definition refugees are those whose migration decision is influenced by

\footnotetext{
${ }^{4}$ Consider the case of migration between two regions for which all skills are perfectly transferable and the wage (or earnings) distributions are the same. Initially workers select random draws from a distribution of wage offerings. Migration takes place only if the random wage draw from the "other place" (destination) is sufficiently in excess of the expected wage in the origin to at least compensate for the costs of migration. With the passage of time, the acquisition of location specific human capital in the labor market and in consumption raise the cost of subsequent moves. If there is a regression to the mean over time in wage draws it would appear that the wages (and occupational status) of migrants decrease with duration in the destination. While this phenomenon may be relevant for internal migration within countries (or groups of countries) that do not have regional differences in earnings or in the transferability of skills, it would not be generally applicable to international or even internal migration.

${ }^{5}$ For example, unskilled farm laborers from Mexico are likely to remain unskilled workers in the United States.
} 
non-economic factors concerning their safety, security, freedom, ideology, ethnicity or social class (political, religious, or some other dimension). ${ }^{6}$ As a result, refugee streams include a larger proportion of immigrants who are less adaptable for migration. ${ }^{7}$ They would include workers skilled in the origin but whose skills have little international transferability (e.g., lawyers, judges, and generals), individuals with fewer decision making skills or less allocative efficiency, and frequently individuals who did not plan for or prepare for the move. As a result, other things being the same, refugees would be expected to have a steeper decline than economic migrants in their occupational status from the origin to the destination, and would have a steeper improvement subsequently as they make investments that increase the transferability of their skills. Because of lingering disadvantages due to their refugee experience and motivations, the gap between them and economic migrants would narrow but in general it would never close. Thus, refugees would have a deeper " $U$ " than economic migrants.

Similarly, tied movers are individuals whose migration decision is determined at least in substantial part by that of another, whether this person is an economic migrant, a refugee or another tied mover. Because their own economic incentives are not paramount, they too would experience a steeper decline and a steeper subsequent increase in occupational status, that is a deeper "U", than economic migrants. Yet, they too will experience lingering disadvantages.

This analysis has generated a number of testable hypotheses:

\footnotetext{
${ }^{6}$ There may be only a weak relation between the true but unknown motives for migration and the visa a migrant uses to enter a country. Whereas we think of refugees as being "pushed," ideological migrants are people who move voluntarily ("pulled") for political, religious or ideological reasons. They would be expected to have a similar occupational mobility pattern as do refugees.

${ }^{7}$ Refugees have lower earnings and employment and higher rates of unemployment than do economic migrants, other variables the same (Chiswick 1979, 1980, 1982).
} 
(1) Immigrants would experience a decline in occupational status from the origin to the destination, with a subsequent increase with duration in the destination.

(2) This U-shaped pattern would be steeper for refugees and for tied (family) migrants than for economic migrants.

(3) The U-shaped pattern should be shallow for those migrating between countries with similar wage distributions and for which the skills of one are highly transferable to the other.

(4) The U-shaped pattern would be steeper for high-skilled immigrants and would be shallow for immigrants who are very low-skilled or unskilled in the origin.

\section{The Longitudinal Data}

The empirical analysis is based on the Longitudinal Survey of Immigrants to Australia (LSIA), a longitudinal survey of recently arrived immigrants who received their visas before entry into Australia. ${ }^{8}$ The population represented in the sample is all Principal Applicants, aged 15 years and over, who arrived in Australia as offshore visaed immigrants in the two-year period of September 1993 to August 1995. The Principal Applicant is the person upon whom the approval to immigrate was based. Excluded from the survey are New Zealand citizens (for whom there is unrestricted mobility to Australia) and those granted a visa while living in Australia.

Principal Applicant immigrants selected for interview were those who settled in State and Territory capital cities (including major urban centers close to capital cities, such as Newcastle and Wollongong), as well as Cairns. Only 4 to 5 percent of the total of Principal Applicant immigrants are excluded from the coverage of the survey because they live outside of those areas.

\footnotetext{
${ }^{8}$ For a study of immigrant earnings in Australia using Census data, see Chiswick and Miller, 1985.
} 
The final LSIA sample was 5,192 Principal Applicant arrivals. This represents about 7 percent of the total Principal Applicants that arrived in the two-year survey period. The population from which the sample was selected at random was stratified according to visa eligibility category ${ }^{9}$ and also by about fifty regions or countries of birth. $^{10}$

The information collected in the personal interview includes demographic characteristics, socioeconomic status, family background, and location details. Data on the Principal Applicant's demographic characteristics include gender, age, marital status, country of birth, ethnicity, and general health. Education level, employment status (before and after migration), and income from all sources (with income from labor market activity being separately identified) are the major socioeconomic status variables.

Immigrants were to be interviewed three times. The first interview was to take place approximately five or six months after arrival, the second interview one year later, and the third interview a further two years later. Thus the third interview took place approximately $31 / 2$ years after migration. The first, second, and third waves of interviews commenced in March 1994, March 1995, and March 1997, respectively. Each wave of interviews was spread over a period of two years. ${ }^{11}$

\footnotetext{
${ }^{9}$ The five main visa categories are Preferential Family (28.4 percent of the male sample), Concessional Family (19.5 percent), Business Skills and Employer Nomination (14.8 percent), Independent (20.3 percent), and Humanitarian (17.1 percent). The Humanitarian category includes individuals who are refugees under the UN definition and people treated as refugees by the Australian authorities.

${ }^{10}$ Principal Applicants in smaller States and Territories were over-sampled. Weights are available to adjust for this. These estimation weights were modified to account for sample attrition between the first and the third waves of the survey. All analyses in this study use relevant estimation weights. Relative weights are used so as not to inflate sample sizes. Experiments show that the use of weights has only a modest effect on the statistical results.

"Between 1994 and 1999 labor market conditions in Australia generally improved. According to the Australian Bureau of Statistics (2000), the aggregate male unemployment rate for each year is 1994: 9.1 percent, 1995: 8.8 percent, 1996: 8.8 percent, 1997: 8.5 percent, 1998: 7.8 percent, 1999: 7.0 percent.
} 
In the first wave of interviews, immigrants were asked about their employment status in the year before they migrated, their current employment status, and also for details on jobs held before they started their current job. This information is used in some of the analyses conducted to determine the status of the "first" job immigrants obtained in Australia. Where the immigrant had held only one job in Australia, obtaining information on the first job is straightforward, whether it is the current job or a job that terminated prior to the first interview. Where the immigrant had held more than one job since arriving in Australia, the first job is not literally the first job but is taken as the job (other than the current job) in which the immigrant was employed for the longest period since arriving in Australia. As the first interview was held around six months after arrival, this method should approximate the status of the first job that the immigrants held after arriving in Australia.

The information collected on employment in the wave two and wave three interviews is obtained using a sequence of questions similar to that for wave one. This information is used in analyses of the status of the job held at the time of the interview, as well as in analyses of the first job that immigrants obtained in Australia. When determining the first job held in Australia for those immigrants who had not been employed in Australia by the time of the previous interview, information can be obtained on (i) the occupation of the first job in Australia where the immigrant has had only one job in Australia; (ii) the occupation of the job (other than for any current job) held for the longest time period for immigrants who have held more than one job. While the period between interviews is one or two years, and hence the information used on the longest job held for immigrants with more than one job over the reference period will not necessarily relate to what is literally the first job in Australia, it will 
relate to what might be termed the first substantive job. For many purposes, this will provide a more meaningful variable for analysis. ${ }^{12}$

The information on the occupations immigrants held before and after migration was coded by the Department of Immigration and Multicultural Affairs to the Australian Standard Classification of Occupations (ASCO) version 1 (see Australian Bureau of Statistics 1990). This coding of occupation is based on the type of work undertaken. Both skill level (e.g., amount of formal education and on-the-job training) and skill specialization (e.g., field of knowledge, tools or equipment used) are used to differentiate occupations. Information is available at the "unit group" level: 282 unit groups (occupational categories) are identified in the ASCO profile of occupations. For the purpose of descriptive statistics and frequency distributions, the data on occupations have been aggregated to the broadest level of the ASCO structure, namely the major group level. There are eight major groups: "Professionals", "Managers and Administrators", "Para-Professionals", "Tradespersons", "Clerks", "Salespersons and Personal Service Workers" (Salespersons), "Plant and Machine Operators and Drivers" (Operators) and "Laborers and Related Workers" (Laborers).

For many purposes, it is useful to work with summary measures of the occupational status of immigrants. The main measure of occupational prestige used in Australia is the ANU3 status attainment scale. ${ }^{13}$ The ANU3 measure has its origin in the prestige ratings of occupations developed in ANU1 and ANU2 indices (Broom, et al., 1977, Jones 1988). The original ANU indices were obtained from a survey that

\footnotetext{
${ }^{12}$ This procedure will result in a more shallow " $U$ " than if there were data on what was literally the very first job after arrival.

${ }^{13}$ Similar measures have been developed for the United States (see, for example, Featherman, et al. 1975 ) and the United Kingdom (see, for example, Goldthorpe and Hope 1974).
} 
asked individuals in medicine, law, teaching and social work occupations to give a rating on a 9-point numeric scale of the general standing of 54 occupations. Regression analysis was then used to link these survey responses to the characteristics of the occupations so that an occupational status scale could be predicted for all occupations. These characteristics included sex, age, birthplace, parent's birthplace, schooling, educational qualifications, housing facilities, and vehicles, among other characteristics.

The ANU3 scale, developed by Jones (1989), measures relative differences in labor market power (authority), occupational prestige, occupational requirements (education and qualifications), and occupational rewards (earnings). The scale ranges from a minimum of zero (ASCO unit group 8901: Ushers and Door Attendants), to a maximum of 100 points (unit group 2303: Specialist Medical Practitioners). ${ }^{14}$ Jones 1989 points out that although the ANU3 scale is based on prestige ratings, it is not strictly equivalent to a prestige scale. Some occupations enjoy a social standing higher than their socioeconomic status as measured by earnings would suggest, such as ministers of religion, dancers, writers and artists. For some other occupations (e.g. chiropractors), the opposite holds. The ANU3 scale has elements of a prestige scale and a measure of socioeconomic status.

The other variables used in the analysis include:

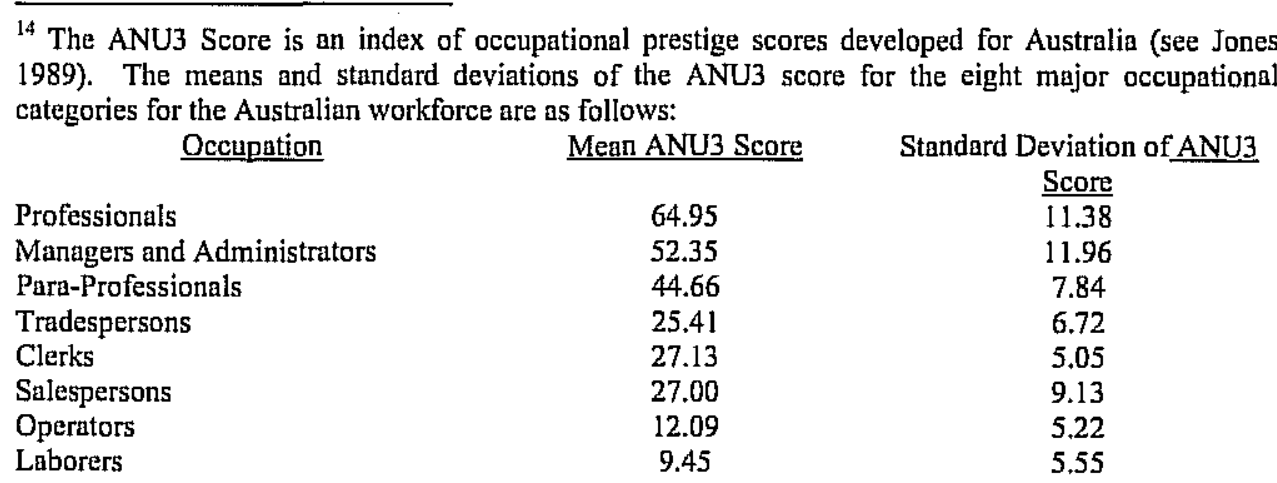


(1) Age-measured in years,

(2) Education Attainment - measured as years of education,

(3) ESDC - dichotomous variable equal to unity if born in an

English-speaking developed country (US, UK, Canada and Ireland),

(4) Birthplace concentration - the percentage of the population in the respondent's postcode area born in the same country or region as the immigrant,

(5) Visa Category - Dichotomous variables equal to unity if Refugee (Humanitarian Category), Preferential Family Category, Concessional Family, or Business Skills/Employer Nominated Scheme, with Independent immigrants as the benchmark, ${ }^{15}$

(6) Length - number of weeks that it took the immigrant to obtain his first job in Australia,

(7) Quartiles - A measure of the occupational status (ANU3) of the last permanent job prior to immigration. Q1 is status scores under $26.2, \mathrm{Q} 2$ is 26.2 to just under $40.5, \mathrm{Q} 3$ is 40.5 to just under 62.5 , and Q4 is 62.5 or higher,

(8) NoEnglish - Did not speak English at the time of immigration.

The means and standard deviations of these variables for males 15 to 64 years of age at immigration are reported in Appendix A.

\footnotetext{
${ }^{15}$ The Business Skills/Employer Nominated and Independent Category immigrants are skills tested and can be considered economic migrants. The Concessional Family and Preferential Family Categories are based on kinship to Australians, although the Consessional Family category includes more distant relatives and a "points test" based on skills and age. The Humanitarian Category is primarily refugees.
} 


\section{Empirical Analysis}

This section begins with a discussion of descriptive statistics for the occupational mobility of male immigrants in Australia from their pre-immigration job through their jobs in wave 1, wave 2 and wave 3 ( 3.5 years after immigration). It then proceeds to the multivariate (econometric) analysis of the level and change in occupational status.

\section{(A) Descriptive Statistics}

Table 1 reports for the male immigrants the occupational distribution in the last job before migrating and the first job in Australia, regardless of the wave in which the first job was reported. Of the 1,354 males reporting a first job in Australia in wave 1 (five to six months after immigrating), their occupational level was lower than the level held by these same workers prior to immigrating. While 55 percent were professionals or managers/administrators prior to immigration, only 43 percent were in these occupations in their first job reported in wave 1. On the other hand, while only 7.1 percent were in operative and laborer occupations prior to immigration, nearly one-quarter (24.4 percent) reported these occupations as their first job in wave 1. Clearly, there was a decline in occupational status from the last job to the first job.

The immigrants who did not have a first post-immigration job to report until a subsequent wave are included in the third and fourth columns of Table 1 . These immigrants took longer to find their first job, either because of unemployment or absence from the labor force. The additions to the sample were less likely to be in high level occupations, and more likely to be in lower skilled occupations. For example, the proportion with a first job in professional and managerial/administrative 
occupations declines from 43 percent in wave 1 to 36 percent when all three waves are included. This is consistent with findings in the literature that among recent immigrants those with lower levels of skill have higher unemployment and lower labor force participation rates (Chiswick and Hurst 1998, Chiswick and Miller 1997).

The occupational status (ANU3) scores can be used to take advantage of information on detailed occupational status. The ANU3 score for those who reported their pre-immigration occupation and their first occupation in wave 1 declined from 47.9 (standard deviation 23.0) for the pre-immigration occupation to 39.41 (standard deviation 25.6) for the first job. Those who took longer to obtain their first job had lower occupational scores, 36.48 (s.d. 25.2) and 35.74 (s.d. 25.0) when wave 2 and wave 3 are also considered.

Table 2 reports by major occupation group the cross-classification of last preimmigration and first post-immigration occupation for those who reported both by wave 3. The diagonals in bold are the proportions who remained in their major occupation group. Thus, 57 percent of professionals remained professionals, 34 percent of managers/administrators remained as managers/administrators and 56 percent of laborers also remained in their pre-immigration occupations. In general there is a decline in occupational status. Using the order of the listing as a rough rank ordering, 36 percent of pre-immigration professionals were in occupations lower than that of professionals and managers/administrators. Among para-professionals, 17 percent improved their occupational status, but 52 percent experienced a decrease in occupational status. Among laborers, perhaps the lowest ranked occupational category, 75 percent had their first job in operator or laborer occupations, 22 percent became tradespersons, clerks and salespersons, and less than 4 percent were in higher 
status occupations.

Table 3 reports the ANU3 score for the post-immigration occupations for the last job in the origin to the first job in wave 1 for the same persons, and then the first job for all those who reported an occupation in wave 3. The scores are reported by the pre-immigration major occupation group. Except for the two lowest occupations, operators and laborers, all the other occupations report a decline from the last occupation to the first occupation. The decline is larger the higher the occupational level.

Those who took more than six months to find a job, that is, they had no job in wave 1 but had one by wave 3, lower the ANU3 score within each pre-immigration occupational category. That is, those who took longer to find a job did less well in their initial job placement than others in their pre-immigration occupational category.

The mean and the standard deviation of the ANU3 score can be computed for the 1,105 males who reported their pre-immigration occupation, their first job and their occupations in waves 1,2 and $3 .^{16}$ The mean ANU3 score declined from 48.2 to 40.8 from the last job to the first job, and then increased from 40.8 to 43.0 from the first job to the job in wave 3 ( 3.5 years after immigration).

\section{(B) Multivariate Analysis}

Table 4 reports the results of the multiple regression (OLS) analysis with the ANU3 occupational status score as the dependent variable. Column (1) is the change

\footnotetext{
16 The mean and standard deviation of the ANU3 status attainment score for male immigrants age 15 to 64 years at immigration:

\begin{tabular}{lcc} 
& Mean & Standard Deviation \\
\cline { 2 - 3 } Pre-Immigration job & 48.21 & 23.02 \\
First job & 40.79 & 25.64 \\
Wave 1 & 40.99 & 25.52 \\
Wave 2 & 42.18 & 24.82 \\
Wave 3 & 42.95 & 24.91
\end{tabular}

Sample size: 1,105

Source: Longitudinal Survey of Immigrants to Australia
} 
in status, that is, it is the ANU3 score for the first job in Australia minus the score for the last job in the origin. Column 2 is the analysis for the level of the occupational status score for the first job in Australia. Greater pre-immigration human capital (i.e., education, older age at migration) and a greater transferability of skills (born in an English-speaking developed country, speaks English at arrival) result in a more favorable occupational status situation, namely a more positive change and a higher level for the first job. Compared with Independent Migrants, Refugees (Humanitarian visas) and the partially tied movers (the two family categories) have a steeper decline from the last job before immigrating to the first job in Australia, and a lower level for the first job. Only those in the Business Skills/Employer Nominated Scheme have a larger improvement and higher first job level than Independent migrants.

Living in an area where many others of one's country of origin live (Birthplace concentration) enhances occupational status among recent immigrants. This may be due to network assistance in job search. However, those who took longer to obtain their first job (LENGTH) in Australia experienced a larger fall and a lower level of occupational status, although the later effect is not statistically significant.

Those who were in higher status jobs prior to immigration (Quartile 4 compared to Quartiles 1 and 2, with Quartile 3 as the benchmark) experienced the larger fall in occupational status. They also experienced a higher occupational status in their first job.

Column (3) in Table 4 reports the results from the change in status from the current job in wave 3 compared to the first occupation in Australia, while column (4) reports the regression results for the status of the wave 3 job. The improvement was greater for those who spoke English at arrival. Most important for explaining 
improvements over time was the visa category at entry. Refugees and family migrants experienced a larger improvement in occupation status in this three-year period than did Independent or Business Skills immigrants. The improvement in occupation over the short span of 3 years is greater for those with higher levels of schooling, who immigrated at a younger age, who were not from an English-speaking developed country and who lived among others from the same origin. While these four coefficients have the signs expected from the model, none of them is statistically significant.

The analysis of occupational attainment at wave 3 (Table 4, column 4) indicates that it is higher for those with more schooling, who immigrated from an English-speaking developed country and who entered under skills based visas as distinct from family or refugee visas. Indeed, the rankings are Business Skills, Independent, then Concessional/Family, and lowest for Refugee (Humanitarian) principal applicants.

\section{Summary and Conclusions}

Based on the immigrant assimilation model, this paper develops hypotheses regarding the occupational mobility of immigrants from their last permanent job in the origin, to their "first" job in the destination, to subsequent jobs in the destination. Due to the less than perfect international transferability of skills there is a decline in occupational attainment from the last job in the origin to the first job in the destination, but due to implicit and explicit post-immigration investments there would then be upward occupational mobility. This is referred to as a U-shaped pattern of occupational mobility. The depth or intensity of the post-migration improvement 
would be related to the depth or intensity of the decline in occupational status at immigration.

The depth of the $U$ is hypothesized to be greater, the lower the international transferability of skills, the higher the level of skills in the origin, and among refugees and tied movers (family migrants) than among economic migrants.

The model and hypotheses are tested using data on adult (non-aged) male Principal Applicants from the Longitudinal Survey of Immigrants to Australia. Data are available on pre-immigration occupation and the occupation in Australia for the "first" job and the jobs held at wave 1 (six months after migration), wave 2 (one year later) and wave 3 (approximately 3.5 years after migration).

The simple cross-tabulation and econometric analyses (using an occupational status score) are supportive of the hypotheses even though the post-migration period is so brief. Occupational status from the last job to the first job fell by more for those whose skills were less readily transferable and who were Refugees or entered under family categories compared to Independent or Business Skills migrants. Higher levels of pre-immigration skill (schooling and experience) resulted in a smaller decline and a higher occupational level for the first job. The subsequent improvements in occupational status from the first job to the job held in wave 3 was greater for those with higher levels of pre-immigration skills and for refugees and those who entered under the family categories.

The analysis implies that the initial occupational status of immigrants may be a poor approximation of their ultimate occupational attainment. Those who have the highest pre-immigration level of skills, more highly transferable skills and who are economic migrants in contrast to refugees and family migrants appear to have the 
most successful occupational attainments. Living in an immigrant/ethnic concentration area appears to raise the occupational status of immigrants, although this effect is at the margin of statistical significance. These findings provide guidance for the design of an immigration policy to enhance the labor market success of those that are admitted.

These findings have been limited by the relatively small size of the sample and especially by the relatively short duration in the destination ( $31 / 2$ years). Yet they do suggest that the immigrant assimilation model can be used successfully to understand the occupational mobility of immigrants. They also suggest that there is substantial research potential from larger and longer term longitudinal surveys of immigrants. 
TABLE 1: Occupational Distributions of Male Immigrants 15-64 Years of Age at Immigration, Longitudinal Survey of Immigrants to Australia

(Percent)

\begin{tabular}{|c|c|c|c|c|}
\hline Occupation & $\begin{array}{c}\text { (i) } \\
\text { Last Job } \\
\text { Before } \\
\text { Migrating }\end{array}$ & $\begin{array}{c}\text { (ii) } \\
\text { First Job in } \\
\text { Australia } \\
\text { (Wave 1) }\end{array}$ & $\begin{array}{c}\text { (iii) } \\
\text { First Job in } \\
\text { Australia } \\
\text { (Waves } 1 \& 2 \text { ) }\end{array}$ & $\begin{array}{c}\text { (iv) } \\
\text { First Job in } \\
\text { Australia } \\
\text { (Waves } 1,2 \& 3 \text { ) }\end{array}$ \\
\hline Professionals & 37.9 & 30.0 & 27.2 & 26.0 \\
\hline $\begin{array}{l}\text { Managers/ } \\
\text { Administrators }\end{array}$ & 17.1 & 12.7 & 11.0 & 10.3 \\
\hline Para-Professionals & 4.0 & 2.9 & 3.5 & 4.4 \\
\hline Tradespersons & 25.3 & 20.3 & 18.7 & 17.3 \\
\hline Clerks & 2.6 & 2.3 & 3.3 & 4.3 \\
\hline Salespersons ${ }^{(\mathfrak{n})}$ & 6.1 & 7.5 & 7.9 & 8.5 \\
\hline Operators $^{(b)}$ & 3.3 & 5.7 & 6.7 & 6.8 \\
\hline Laborers $^{(\mathrm{c})}$ & 3.8 & 18.7 & 21.7 & 22.5 \\
\hline Total Males & 100.0 & 100.0 & 100.0 & 100.0 \\
\hline Sample size & 1354 & 1354 & 1914 & 2272 \\
\hline
\end{tabular}

(a) Salespersons include personal service workers.

(b) Operators include plant and machine operators and drivers.

(c) Laborers include laborers and related workers.

Source: Longitudinal Survey of Immigrants to Australia. 
TABLE 2: Occupational Change from Last Pre-Immigration to First Post-Immigration Job for Male Immigrants 15-64 Years of Age at Immigration, Longitudinal Survey of Immigrants to Australia (Percent)

\begin{tabular}{|c|c|c|c|c|c|c|c|c|c|c|}
\hline \multirow[b]{2}{*}{$\begin{array}{l}\text { Pre-Immigration } \\
\text { Occupation }^{(\mathrm{a})}\end{array}$} & \multicolumn{10}{|c|}{ FIRST Post-Immigration Occupation } \\
\hline & Professionals & $\begin{array}{c}\text { Managers/ } \\
\text { Admin- } \\
\text { istrators }\end{array}$ & $\begin{array}{c}\text { Para- } \\
\text { Professionals }\end{array}$ & $\begin{array}{l}\text { Trades- } \\
\text { persons }\end{array}$ & Clerks & Salespersons & Operators & Laborers & Total ${ }^{(b),(c)}$ & $\begin{array}{c}\% \\
\text { Distrib } \\
\text { ution }^{\text {(c) }} \\
\end{array}$ \\
\hline Professionals & $\mathbf{5 7 . 3}$ & 7.0 & 3.8 & 5.4 & 5.1 & 5.0 & 2.7 & 13.6 & 100.0 & 32.3 \\
\hline $\begin{array}{l}\text { Managers/ } \\
\text { Administrators }\end{array}$ & 9.6 & 34.0 & 1.6 & 9.7 & 3.0 & 10.0 & 10.2 & 21.9 & 100.0 & 14.3 \\
\hline Para-Professionals & 15.2 & 2.2 & 30.1 & 12.0 & 5.6 & 7.8 & 8.8 & 18.3 & 100.0 & 5.4 \\
\hline Tradespersons & 0.7 & 1.7 & 1.9 & 56.4 & 0.5 & 3.4 & 6.4 & 29.0 & 100.0 & 26.8 \\
\hline Clerks & 6.0 & 0.8 & 1.8 & 2.0 & 23.7 & 24.4 & 1.7 & 39.6 & 100.0 & 3.8 \\
\hline Salespersons & 11.3 & 4.2 & 0.0 & 5.3 & 2.5 & 28.5 & 10.7 & 37.7 & 100.0 & 9.3 \\
\hline Operators & 1.5 & 0.3 & 0.0 & 11.5 & 0.0 & 7.2 & 36.0 & 43.5 & 100.0 & 3.1 \\
\hline Laborers & 0.9 & 0.4 & 2.3 & 12.5 & 1.3 & 8.0 & 18.6 & 56.0 & 100.0 & 5.0 \\
\hline$\%$ Distribution $^{(c)}$ & 22.3 & 8.2 & 3.8 & 20.4 & 3.7 & 8.6 & 7.6 & 25.4 & 100.0 & 100.0 \\
\hline
\end{tabular}

(a)Salesperson include personal service workers; Operators include plant and machiner operators and drivers; Laborers include laborers and related workers.

(b) The total number of cases is 2039. All data are weighted using sample weights to reflect a population of 25,629 .

(c) Total may not sum to 100.0 due to rounding.

Source: Longitudinal Survey of Immigrants to Australin 
TABLE 3: Means of ANU3 Status Attainment Score for First Jobs in Australia by Pre-Immigration Occupational Group for Male Immigrants 15-64 Years of Age at Immigration, Longitudinal Survey of Immigrants to Australia

\begin{tabular}{|c|c|c|c|}
\hline $\begin{array}{l}\text { Pre-immigration } \\
\text { Occupation }^{\text {(a) }}\end{array}$ & $\begin{array}{c}\text { Last Job Before } \\
\text { Migrating }\end{array}$ & Wave $1^{(b)}$ & Wave $3^{(\mathrm{c})}$ \\
\hline Professionals & 67.96 & 55.78 & 49.82 \\
\hline $\begin{array}{l}\text { Managers/ } \\
\text { Administrators }\end{array}$ & 61.16 & 46.95 & 43.54 \\
\hline Para-Professionals & 41.59 & 34.79 & 33.61 \\
\hline Tradespersons & 26.62 & 21.83 & 20.13 \\
\hline Clerks & 25.83 & 25.46 & 24.37 \\
\hline Salespersons ${ }^{(a)}$ & 31.65 & 26.40 & 23.43 \\
\hline Operators & 13.62 & 15.25 & 14.24 \\
\hline Laborers & 10.54 & 15.42 & 14.33 \\
\hline Total & 47.90 & 39.41 & 35.74 \\
\hline Sample size & 1354 & 1354 & 2273 \\
\hline
\end{tabular}

(n) Salespersons include personal service workers; Operators include plant and machine operators and drivers; Laborers include laborers and related workers.

(b) Means for the first job for those immigrants who had obtained a job in Australia by the time of the wave 1 interview.

(c) Means for the first job for the larger group of immigrants who had obtained a job in Australia by the time of the wave 3 interview.

Source: Longitudinal Survey of Immigrants to Australia 
TABLE 4: Status and Changes in Status of Jobs in Australia of Males Immigrants 15-64 Years of Age at Immigration, Longitudinal Survey of Immigrants to Australia

\begin{tabular}{|c|c|c|c|c|}
\hline Variable & $(1)^{(1)}$ & $(2)^{(\mathrm{b})}$ & $(3)^{(\mathrm{C})}$ & $(4)^{(d)}$ \\
\hline Constant & $\begin{array}{c}-44.244 \\
(6.08)\end{array}$ & $\begin{array}{l}-2.024 \\
(0.27)\end{array}$ & $\begin{array}{l}2.197 \\
(0.67)\end{array}$ & $\begin{array}{c}-13.953 \\
(3.65)\end{array}$ \\
\hline Education & $\begin{array}{l}0.738 \\
(3.88)\end{array}$ & $\begin{array}{l}1.277 \\
(6.59)\end{array}$ & $\begin{array}{l}0.172 \\
(1.03)\end{array}$ & $\begin{array}{c}3.380 \\
(17.70)\end{array}$ \\
\hline Age at migration & $\begin{array}{l}1.358 \\
(3.75)\end{array}$ & $\begin{array}{l}1.485 \\
(4.02)\end{array}$ & $\begin{array}{r}-0.046 \\
(0.73)\end{array}$ & $\begin{array}{l}0.113 \\
(1.48)\end{array}$ \\
\hline (Age at migration) $^{2}$ & $\begin{array}{l}-0.017 \\
(3.62)\end{array}$ & $\begin{array}{l}-0.019 \\
(3.94)\end{array}$ & (e) & (e) \\
\hline $\begin{array}{l}\text { English-speaking } \\
\text { developed countries }\end{array}$ & $\begin{array}{l}8.038 \\
(6.09)\end{array}$ & $\begin{array}{r}8.572 \\
(6.37)\end{array}$ & $\begin{array}{l}-1.393 \\
(0.98)\end{array}$ & $\begin{array}{l}7.711 \\
(4.41)\end{array}$ \\
\hline $\begin{array}{l}\text { Visa Category (Indep } \\
\text { Refugee } \\
\text { (Humanitarian) }\end{array}$ & $\begin{array}{l}n t) \\
-11.191 \\
(6.16)\end{array}$ & $\begin{array}{c}-12.361 \\
(6.67)\end{array}$ & $\begin{array}{l}3.430 \\
(2.10)\end{array}$ & $\begin{array}{c}-17.131 \\
(9.78)\end{array}$ \\
\hline $\begin{array}{l}\text { Preferential } \\
\text { Family }\end{array}$ & $\begin{array}{l}-6.358 \\
(5.85)\end{array}$ & $\begin{array}{l}-6.966 \\
(6.28)\end{array}$ & $\begin{array}{l}2.477 \\
(2.32)\end{array}$ & $\begin{array}{l}-8.332 \\
(6.43)\end{array}$ \\
\hline $\begin{array}{l}\text { Concessional } \\
\text { Family }\end{array}$ & $\begin{array}{l}-6.562 \\
(4.77)\end{array}$ & $\begin{array}{l}-7.078 \\
(5.04)\end{array}$ & $\begin{array}{l}1.719 \\
(1.23)\end{array}$ & $\begin{array}{l}-8.236 \\
(4.77)\end{array}$ \\
\hline $\begin{array}{l}\text { Business } \\
\text { Skills/ENS }\end{array}$ & $\begin{array}{l}13.021 \\
(7.04)\end{array}$ & $\begin{array}{l}15.337 \\
(8.13)\end{array}$ & $\begin{array}{l}-0.928 \\
(0.50)\end{array}$ & $\begin{array}{l}15.934 \\
(7.13)\end{array}$ \\
\hline $\begin{array}{l}\text { Birthplace } \\
\text { concentration }\end{array}$ & $\begin{array}{l}0.239 \\
(2.73)\end{array}$ & $\begin{array}{l}0.156 \\
(1.75)\end{array}$ & $\begin{array}{l}0.052 \\
(0.61)\end{array}$ & $\begin{array}{l}0.191 \\
(1.80)\end{array}$ \\
\hline $\begin{array}{l}\text { Length } \\
\text { (weeks) }\end{array}$ & $\begin{array}{l}-0.027 \\
(1.97)\end{array}$ & $\begin{array}{l}-0.017 \\
(1.20)\end{array}$ & $\begin{array}{l}-0.017 \\
(1.33)\end{array}$ & (e) \\
\hline $\begin{array}{l}\text { No English } \\
\text { at arrival }\end{array}$ & $\begin{array}{l}-3.258 \\
(2.63)\end{array}$ & $\begin{array}{l}-4.497 \\
(3.56)\end{array}$ & $\begin{array}{l}-3.062 \\
(2.60)\end{array}$ & (t) \\
\hline Quartile 1 & $\begin{array}{l}14.142 \\
(11.20)\end{array}$ & $\begin{array}{l}-17.659 \\
(13.72)\end{array}$ & (c) & (e) \\
\hline Quartile 2 & $\begin{array}{l}4.150 \\
(3.47)\end{array}$ & $\begin{array}{l}-14.783 \\
(12.11)\end{array}$ & (e) & (e) \\
\hline
\end{tabular}




\begin{tabular}{lcccc} 
Quartile 4 & -18.039 & 0.985 & (c) & (e) \\
& $(14.73)$ & $(0.79)$ & & \\
$\bar{R}^{2}$ & 0.309 & 0.466 & 0.008 & 0.390 \\
Sample size & 1678 & 1678 & 1296 & 1378 \\
\hline
\end{tabular}

Note: ' $t$ ' statistics in parentheses.

${ }^{(a)}$ Changes in status between pre- and post-immigration jobs.

(b) Status of first job in Australia.

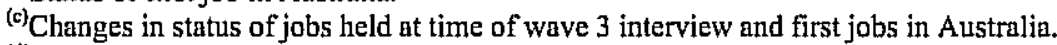

(d) Status of job held at wave 3 interview.

(a) Variable not entered.

(1)ENS denotes Employer Nomination Scheme.

Source: Longitudinal Survey of Immigrants to Australia 


\section{REFERENCES}

Australian Bureau of Statistics (1990). Australian Standard Classification of Occupations (First Edition), Australian Bureau of Statistics, Canberra.

Australian Bureau of Statistics (2000). Australian Economic Indicators, Catalogue 1350.0, December, Australian Bureau of Statistics, Canberra.

Borjas, George (1985). "Assimilation, Changes in Cohort Quality, and the Earnings of Immigrants", Journal of Labor Economics, Vol. 3, No. 4, pp. 463-489.

Borjas, George (1989). "Immigrant and Emigrant Earnings: A Longitudinal Study", Economic Inquiry, Vol. 27, No. 1, pp. 21-37.

Broom, Leonard, Paul Duncan-Jones, Frank L. Jones and Patrick McDonnell (1977). 'Investigating Social Mobility', Department of Sociology, the Research School of Social Sciences, Departmental Monograph no. 1, Australian National University.

Brown, Randall S., Marilyn Moon and Barbara S. Zoloth (1980). "Occupational Attainment and Segregation by Sex", Industrial and Labor Relations Review, Vol. 33, No. 4, pp. 506-517.

Chiswick, Barry R. (1977). "A Longitudinal Analysis of the Occupational Mobility of Immigrants" in Barbara D. Dennis, ed. Proceedings of the $30^{\text {th }}$ Annual Winter Meetings, Industrial Relations Research Association, Madison, IRRA, pp. 2027.

Chiswick, Barry R. (1978). "The Effect of Americanization on the Earnings of Foreign-Born Men", Journal of Political Economy, Vol. 85, No. 5, pp. 897-921.

Chiswick, Barry R. (1979). "The Economics Progress of Immigrants: Some Apparently Universal Patterns", in William Fellner, ed. Contemporary Economic Problems 1979, American Enterprise Institute, Washington, pp. 357399.

Chiswick, Barry R. (1980). An Analysis of the Economic Progress and Impact of Immigrants, National Technical Information Services, NTIS No. PB80-200454, Washington, August 1980.

Chiswick, Barry R. (1982). The Employment of Immigrants in the United States, American Enterprise Institute, Washington.

Chiswick, Barry R. (1986). "Is the New Immigration Less Skilled than the Old?" Joumal of Labor Economics, Vol. 4, No. 2, pp. 168-192. 
Chiswick, Barry R. and Michael Hurst (1998). "The Labor Market Status of Immigrants: A Synthesis", in Hermann Kurthen, et al., eds., Immigration, Citizenship and the Welfare State in Germany and the United States: Immigrant Incorporation, JAI Press, Stamford, CN, pp. 73-94.

Chiswick, Barry R. and Paul W. Miller (1985). "Immigrant Generation and Income in Australia", Economic Record, Vol. 61, No. 173, pp. 540-553.

Chiswick, Barry R. and Paul W. Miller (1997). "Literacy, Numeracy and the Labour Market", in Aspects of Literacy: Assessed Skill Levels, Australian Bureau of Statistics, Canberra, Catalogue No. 4228.0, pp. 73-79.

Chiswick, Barry R. and Paul W. Miller (forthcoming). "The Complementarity of Language and Other Human Capital: Immigrant Earnings in Canada" Economics of Education Review.

Duleep, Harriet and Mark Regets (1996). "The Elusive Concept of Immigrant Quality: Evidence from 1970-1990", Discussion Paper PRIP.UI-41, Program for Research on Immigration Policy, Urban Institute, Washington, DC.

Duleep, Harriet and Mark Regets (1997). "Measuring Immigrant Wage Growth Using Matched CPS Files", Demography, Vol. 34, No. 2, pp. 239-249.

Featherman, David L., Frank L. Jones and Robert M. Hauser (1975). "Assumptions of Social Mobility Research in the US: The Case of Occupational Status", Social Science Research, Vol. 4, pp. 329-360.

Goldthorpe, John H. and Keith Hope (1974). The Social Grading of Occupations: A New Approach and Scale, Clarendon Press, Oxford.

Jones, Frank L. (1988). "Stratification Approaches to Class Measurement", Australian and New Zealand Journal of Sociology, Vol. 24, No. 2, pp. 279-284.

Jones, Frank L. (1989). "Occupational Prestige in Australia: A New Scale", Australian and New Zealand Journal of Sociology, Vol. 25, No. 2, pp. 187-199.

Leigh, Duane E. (1975). "Occupational Advancement in the Late 1960s: An Indirect Test of the Dual Labor Market Hypothesis", Journal of Human Resources, Vol. 11 , pp. 155-171.

Miller, Paul W. and Paul A. Volker (1985). "Economic Progress in Australia: An Analysis of Occupational Mobility", Economic Record, Vol. 61, No. 172, pp. 463-475.

Nickell, Stephan (1982). "The Determinants of Occupational Success in Britain", Review of Economic Studies, Vol. 49, pp. 43-53. 
Schmidt, Peter and Robert P. Strauss (1975). "The Prediction of Occupation Using Multiple Logit Models", International Economic Review, Vol. 16, No. 2, pp. 471-486. 


\section{APPENDIX A}

TABLE A1: Means and Standard Deviations of Variables, Male Immigrants 15-64 Years of Age at Immigration, Longitudinal Survey of Immigrants to Australia.

\begin{tabular}{|c|c|c|c|c|c|}
\hline Variable & Mean & $\begin{array}{l}\text { Standard } \\
\text { Deviation }\end{array}$ & Variable & Mean & $\begin{array}{c}\text { Standard } \\
\text { Deviation }\end{array}$ \\
\hline Socioeconomic & & & Visa Category & & \\
\hline ANU3 status score & 35.429 & 25.041 & Refugee & 0.082 & 0.275 \\
\hline Age & 34.166 & 8.040 & Preferential Family & 0.246 & 0.431 \\
\hline Educational Attainment & 15.079 & 2.998 & $\begin{array}{l}\text { Concessional } \\
\text { Family }\end{array}$ & 0.249 & 0.432 \\
\hline Birthplace Concentration & 2.670 & 4.357 & $\begin{array}{l}\text { Business } \\
\text { Skills/ENS }\end{array}$ & 0.185 & 0.388 \\
\hline $\begin{array}{l}\text { No English at arrival } \\
\text { Length (weeks) to first } \\
\text { job }\end{array}$ & $\begin{array}{c}0.294 \\
25.892\end{array}$ & $\begin{array}{c}0.456 \\
36.954\end{array}$ & $\begin{array}{l}\text { Independent } \\
\text { Pre-Immigration } \\
\text { Skill Level }\end{array}$ & 0.239 & 0.427 \\
\hline & & & Quartile 1 ${ }^{\text {(b) }}$ & 0.223 & 0.416 \\
\hline Birthplace & & & Quartile 2 & 0.215 & 0.411 \\
\hline English-speaking & 0.095 & 0.293 & Quartile 3 & 0.247 & 0.432 \\
\hline Developed Countries & & & Quartile 4 & 0.315 & 0.465 \\
\hline
\end{tabular}

${ }^{(0)}$ ENS denotes Employer Nomination Scheme.

(b) The quartiles are formed using unweighted data for all workers. Deviations from 0.25 are due to the restriction of the sample to males and the use of weighted data.

Source: Longitudinal Survey of Immigrants to Australia. 